Fixed Point Theory, 22(2021), No. 2, 663-670

DOI: $10.24193 /$ fpt-ro.2021.2.43

http://www.math.ubbcluj.ro/ nodeacj/sfptcj.html

\title{
ON MULTIVALUED P-CONTRACTIVE MAPPINGS THAT BELONGS TO CLASS OF WEAKLY PICARD OPERATORS
}

\author{
HATICE ASLAN HANÇER \\ Department of Mathematics, Faculty of Science and Arts, Kirikkale University, \\ 71450 Yahsihan, Kirikkale, Turkey \\ E-mail: haticeaslanhancer@gmail.com
}

\begin{abstract}
In the present paper, by introducing the $P$-contractivity of a multivalued mapping, we give a new class of multivalued weakly Picard operators on complete metric spaces and show that the class of multivalued contractions is a proper subset of this new class. We also give a nontrivial example showing this fact.
\end{abstract}

Key Words and Phrases: Fixed point, multivalued mapping, weakly Picard operator.

2020 Mathematics Subject Classification: 54H25, 47H10.

Acknowledgement. The author would like to thank the referees for their helpful advice which led them to present this paper.

\section{REFERENCES}

[1] I. Altun, G. Durmaz, M. Olgun, P-contractive mappings on metric spaces, Journal of Nonlinear Functional Analysis, 2018(2018), Article ID 43, pp. 1-7.

[2] I. Altun, G. Mınak, H. Dağ, Multivalued F-contractions on complete metric space, Journal of Nonlinear and Convex Analysis, 16(2015), no. 4, 659-666.

[3] M. Berinde, V. Berinde, On a general class of multi-valued weakly Picard mappings, J. Math. Anal. Appl., 326(2007), 772-782.

[4] V. Berinde, M. Păcurar, The role of the Pompeiu-Hausdorff metric in fixed point theory, Creat. Math. Inform., 22(2013), no. 2, 35-42.

[5] Lj. B. Ćirić, Multivalued nonlinear contraction mappings, Nonlinear Anal., 71(2009), 2716-2723.

[6] Lj. B. Ćirić, J.S. Ume, Common fixed point theorems for multivalued nonself mappings, Publ. Math. Debrecen, 60(2002), 359-371.

[7] P.Z. Daffer, H. Kaneko, Fixed points of generalized contractive multivalued mappings, J. Math. Anal. Appl., 192(1995), 655-666.

[8] Y. Feng, S. Liu, Fixed point theorems for multivalued contractive mappings and multivalued Caristi type mappings, J. Math. Anal. Appl., 317(2006), 103-112.

[9] A. Fulga, A. Proca, A new generalization of Wardowski fixed point theorem in complete metric spaces, Advances in the Theory of Nonlinear Analysis and its Applications, 1(2017), no. 1, $57-63$.

[10] A. Fulga, A.M. Proca, Fixed points for $\varphi_{E}$-Geraghty contractions, J. Nonlinear Sci. Appl., 10(9)(2017), 5125-5131.

[11] H.A. Hançer, G. Minak, I. Altun, On a broad category of multivalued weakly Picard operators, Fixed Point Theory, 18(2017), no. 1, 229-236. 
[12] V.I. Istrăţescu, Fixed Point Theory. An Introduction, Dordrecht D. Reidel Publishing Company 1981.

[13] T. Kamran, Q. Kiran, Fixed point theorems for multivalued mappings obtained by altering distances, Math. Comput. Modelling, 54(2011), 2772-2777.

[14] D. Klim, D. Wardowski, Fixed point theorems for set-valued contractions in complete metric spaces, J. Math. Anal. Appl., 334(2007), 132-139.

[15] N. Mizoguchi, W. Takahashi, Fixed point theorems for multivalued mappings on complete metric spaces, J. Math. Anal. Appl., 141(1989), 177-188.

[16] S.B. Nadler, Multi-valued contraction mappings, Pacific J. Math., 30(1969), 475-488.

[17] A. Petruşel, Multivalued weakly Picard operators and applications, Scientiae Mathematicae Japonicae, 59(2004), no. 1, 169-202.

[18] A. Petruşel, I.A. Rus, M.A. Şerban, Basic problems of the metric fixed point theory and the relevance of a metric fixed point theorem for multivalued operators, J. Nonlinear Convex Anal., 15(2014), 493-513.

[19] O. Popescu, A new type of contractive mappings in complete metric spaces, Bull. of Transilvania Univ. Braşov, 50(2008), 479-482.

[20] S. Reich, Fixed points of contractive functions, Boll. Un. Mat. Ital., 4(5)(1972), 26-42.

[21] S. Reich, Some problems and results in fixed point theory, Topological Methods in Nonlinear Functional Analysis (Toronto, Ont., 1982), 179-187, Contemp. Math., 21, Amer. Math. Soc., Providence, RI, 1983.

[22] I.A. Rus, Basic problems of the metric fixed point theory revisited (II), Stud. Univ. Babeş-Bolyai Math., 36(1991), 81-99.

[23] I.A. Rus, A. Petruşel, G. Petruşel, Fixed Point Theory, Cluj University Press, 2008.

[24] T. Suzuki, Mizoguchi-Takahashi's fixed point theorem is a real generalization of Nadler's, J. Math. Anal. Appl., 340(2008), 752-755.

Received: February 28, 2019; Accepted: January 7, 2020. 